\title{
HUBUNGAN ANTARA USIA, PARITAS DAN PENDIDIKAN IBU TENTANG PEMERIKSAAN PAP SMEAR DI YAYASAN KANKER INDONESIA TAHUN 2017
}

\author{
Vivi Oktari \\ STIKES Pembina Palembang \\ Program Studi D-III Kebidanan
}

\author{
Informasi Artikel : \\ Diterima : $\quad$ September 2018 \\ Disetujui : $\quad$ Desember 2018 \\ ${ }^{*}$ Korespondensi Penulis : \\ Vivioktari26@gmail.com
}

\begin{abstract}
A B S T R A K
Pap Smear adalah merupakan pemeriksaan sitologi untuk mendeteksi secara dini kanker leher rahim, bahkan dapat mendeteksi pada stadium pra kanker, selain itu pap smear juga dapat mendeteksi adanya infeksi pada jalan lahir.Tujuan penelitian ini adalah untuk mengetahui hubungan antara usia, paritas dan pendidikan ibu dengan pemeriksaan pap smear di Yayasan Kanker Indonesia Cabang Sumatera Selatan tahun 2017.Desain penelitian ini menggunakan survei analitik melalui pendekatan Cross Sectional dimana data ini menyangkut variabel Independen (usia, paritas dan pendidikan) dan variabel Dependen (pemeriksaan pap smear). Populasi dalam penelitian ini adalah seluruh ibu yang berkunjung di Yayasan Kanker Indonesia Cabang Sumatera Selatan, dengan teknik total sampling diperoleh besar 368 orang. Berdasarkan Univariat didapatkan ibu yang melakukan pemeriksaan pap smear lebih banyak berjumlah 266 orang $(72,3 \%)$ dibandingkan yang tidak melakukan pemeriksaan pap smear berjumlah 102 orang $(27,7 \%)$. Ibu yang memiliki usia resiko tinggi lebih banyak berjumlah 259 responden $(70,4)$ dibandingkan ibu yang memiliki usia resiko rendah berjumlah 109 responden $(29,6)$. Ibu yang memiliki paritas rendah lebih banyak berjumlah 300 responden $(81 \%)$ dibandingkan ibu yang memiliki paritas tinggi berjumlah 68 responden $(18,5)$. dan ibu yang berpendidikan tinggi lebih banyak berjumlah 212 responden $(57,6)$ dibandingkan ibu yang berpendidikan rendah berjumlah 156 responden $(42,4)$. Hasil uji Chi-square menunjukkan ada hubungan yang bermakna antara usia ( $\rho$ value 0,001$)$, paritas ( $\rho$ value 0,022$)$ dan pendidikan $(\rho$ value 0,000$)$ ibu dengan pemeriksaan pap smear di Yayasan Kanker Indonesia Cabang Sumatera Selatan. Diharapkan pada tenaga kesehatan Yayasan Kanker Indonesia Cabang Sumatera Selatan agar lebih meningkatkan penyuluhan mengenai kesehatan reproduksi terutama bahaya kanker serviks dan pentingnya pemeriksaan pap smear sehingga dapat turut membantu menurunkan angka kejadian kanker serviks dan meningkatkan derajat kesehatan kaum wanita.
\end{abstract}

Kata Kunci : Pemeriksaan Pap Smear, Usia, Paritas dan Pendidikan 
mother numbered 156 respondents $(42,4 \%)$. Result of chi-square test showed that there is a significant correlation between age ( $\rho$ value 0,001), parity ( $\rho$ value 0,022) and education ( $\rho$ value 0,000) mother with Pap Smear Examination In Indonesia Cancer Foundation Branch South Sumatra. Expected to the healt worker of Indonesia Cancer Foundation Branch South Sumatera in order to more increase couseling about reproduction health mainly the danger of sevix cancer and the infortance of pap smear examination so that can help to decrease servix cancer rate incidence and increasing women health rate.

\section{Keyword : Pap Smear Examination, Age, Parity and Education}

\section{PENDAHULUAN}

Penyakit kanker secara umum dapat didefinisikan sebagai suatu penyakit yang disebabkan oleh pertumbuhan sel-sel jaringan tubuh yang tidak normal. Sel-sel kanker akan berkembang dengan cepat, tidak terkendali, dan terus membelah diri. Selanjutnya menyusup ke jaringan sekitarnya (invasive) dan terus menyebar melalui jaringan ikat, darah, serta menyerang organ-organ penting dan saraf tulang belakang (Savitri, 2015).

Pap Smear merupakan suatu metode untuk pemeriksaan sel cairan dinding leher rahim dengan mengunakan mikroskop, yang dilakukan secara cepat, tidak sakit, dan dengan biaya yang relative terjang kau serta hasil yang akurat. (Irianto, 2015)

Pemeriksaan Pap Smear bertujuan untuk mendeteksi sel-sel yang tidak normal yang dapat berkembang menjadi kankerservik. Sedangkan wanita yang dianjurkan pemeriksaan pap smear ini adalah wanita yang telah aktif melakukan hubungan seksual, biasanya wanita dalam masa usia subur, karena tingkat seksualnya lebih tinggi sehingga lebih tinggi resiko kanker servik bagi mereka. Namun tidak menjadi kemungkinan juga wanita yang tidak mengalami aktivitas seksualnya memeriksaan diri. (Irianto, 2015).

Penyakit kanker secara umum dapat didefinisikan sebagai suatu penyakityang disebabkan oleh pertumbuhan sel-sel jaringan tubuh yang tidak normal. Sel-sel kanker akan berkembang dengan cepat, tidak terkendali, dan terus membelah diri. Selanjutnya menyusup ke jaringan sekitarnya (invasive) danterus menyebar melalui jaringan ikat, darah, serta menyerang organ-organpenting dan saraf tulang belakang. (Savitri , 2015).

Menurut World Health Oganization (WHO) Kanker serviks merupakan salah satu permasalahan dalam kesehatan reproduksi. Kanker serviks adalah keganasan yang terjadi pada leher rahim. Kanker serviks merupakan kanker kedua yang paling sering terjadi di seluruh dunia Kasus kanker serviks pada tahun 2012 terdapat 528000 kasus baru, yang telah didiagnosis di seluruh dunia dan $85 \%$ terjadi di daerah yang kurang berkembang.

Kanker serviks menyebabkan 266000 wanita meninggal karena kanker serviks setiap tahun. Kanker serviks mewakili 7,5\% kematian dari semua kematian yang disebabkan oleh kanker pada perempuan. (WHO, 2014).

Sustainable Development Goals (SDGs) yaitu pembangunan berkelanjutan sebagai agenda pembangunan global baru untuk periode 2016 hingga 2030 meneruskan pencapaian Millenium Development Goals (MDGs) yang telah berakhir pada tahun 2015. Tujuan SDGs yang ke-3 adalah meningkatkan kesehatan yang baik dengan target yang akan dicapai yaitu mengurangi sepertiga kematian akibat penyakit tidak menular. Kanker serviks merupakan salah satu penyakit yang tidak menular. (Kemenkes, 2015).

Kanker serviks merupakan kanker dengan prevalensi tertinggi di Indonesia, sedangkan kanker terbesar selanjutnyaadalah kanker payudara dan kanker prostat. Prevalensi kanker serviks yaitu sekitar $0,8 \%$ atau sekitar 98.692 penderita kanker serviks di Indonesia dan selanjutnya kanker payudara sebesar $0,5 \%$ atau sekitar 61.682 penderita dansebesar $0,2 \%$ atau sekitar 25.012 penderita kanker prostat di Indonesia. Provinsi yang memiliki prevalensi kanker serviks tertinggi yaitu Provinsi Kepulauan Riau, Provinsi Maluku Utara dan Provinsi D.I. Yogyakarta dengan sebesar 1,5\% dari seluruh penderita kanker di Indonesia. (Kemenkes RI, 2015).

Kanker leher rahim sampai saat ini masih merupakan masalah kesehatan wanita di seluruh dunia baik di Negara maju maupun berkembang termasuk Indonesia. Di negara maju kanker leher rahim menduduki peringkat ke 10 dari semua keganasan, sedangkan dinegara berkembang masih menduduki peringkat pertama dan merupakan penyebab utama kematian pada perempuan. (Depkes, 2014)

Pap smear di Indonesia telah terbukti mampu meningkatkan temuan kanker serviks stadium dini dan lesi prakanker. Hal ini 
dikarenakan bahwa kuantitas sumber daya manusia yang baik, sebanyak 627 orang dari jumlah wanita usia subur. Sebagian besar peserta melaksanakan pap smear setelah mendapatkan pengarahan maupun anjuran dari orang lain dan banyak juga yang telah mongetahui tentang pap smear dan telah mengikuti seminar tentang pap smear. Belum adanya kesadaran wanita melakukan pap smear karena wanita kurang dalam pengetahuan tentang pap smear sehingga berdampak pada belum menyadari tentang arti pentingnya pemeriksaan pap smear meskipun telah ada anggota pada tahun 2013 di Yayasan Kangker Indonesia (YKI) yang meninggal.(PKBI, 2014).

Kanker serviks merupakan infeksi kronik leher rahim yang disebabkan oleh satu atau lebih virus HPV (Human Papiloma Virus) tipe onkogenik resiko tinggi.11 Data Kementerian Kesehatan RI menyebutkan bahwa jumlah kasus kanker serviks di Indonesia sebesar 16 per 100.000 wanita dengan perkiraan munculnya kasus baru 4045 kasus dan 20-25 kematian tiap harinya.7 Peningkatan jumlah kasus baru dan kematian akibat kanker serviks selama 4 tahun berturutturut juga dilaporkan terjadi di Rumah Sakit Kanker Dharmais yaitu 296 kasus baru dan 35 kematian pada tahun 2010, 300 kasus baru dan 36 kematian pada tahun 2011, 343 kasus baru dan 42 kematian pada tahun 2012, 396 kasus baru dan 65 kematian pada tahun 2013.8 Kanker serviks di Provinsi Sumatera Selatan, menjadi penyakit dengan jumlah kasus terbanyak dibandingkan jenis kanker lainnya yaitu sebesar 797 kasus pada tahun 2014. (Dinkes provinsi Sumatera Selatan, 2014)

Tujuan Tes Pap adalah menemukan sel abnormal atau sel yang dapat berkembang menjadikan infeksi HPV. Kanker serviks merupakan penyakit menular seksual, bila penyakit prakanker/ dysplasia di temukan lebih dini kemungkinan angka penyembuhan mencapai 80-90 $\%$ tergantung beratnya lesi dan cara pengobatannya. (Savitri, 2015)

Berdasarkan data di Yayasan Kanker Indonesia (YKI) cabang sumatera selatan palembang pada tahun 2014 berjumlah 569 yang melakukan pemeriksaan pap smear, 362 diantaranya terdeteksi kanker serviks, pada tahun 2015 berjumlah 692 yang melakukan pemeriksaan pap smear, 462 diantaranya terdeteksi kanker serviks serta pada tahun 2016 berjumlah 276 yang melakukan pemeriksaan pap smear, 219 diantaranya terdeteksi kanker serviks. (Yayasan Kanker Indonesia Palembang, 2017).

\section{METODE PENELITIAN}

Penelitian ini termasuk Kuantitatif bersifat analitik dengan menggunakan rancangan penelitian cross sectional merupakan suatu penelitian untuk mempelajari dinamika korelasi antara fakta-fakta dengan efek, dengan cara pendekatan, observasi atau pengumpulan data sekaligus pada suatu saat (point time approach), dimana variabel independen Usia, paritas dan pendidikan dan dikumpulkan sekaligus dalam waktu yang sama (Hidayat , 2014).

Populasi dalam penelitian ini adalah semua wanita yang ingin melakukan pemeriksaan pap smear dan sebagaian wanita yang tidak ingin melakukan pemeriksaan pap smear berjumlah 368 di Yayasan Kanker Indonesia Palembang Tahun 2017. Pengambilan sampel dengan menggunakan teknik total sampling yaitu mengambil sampel dengan jumlah sampel yang ada pada saat penelitiandilakukan.

\section{HASIL PENELITIAN}

\section{a. Analisa Univariat}

Analisis data digunakan untuk menjawab rumusan penelitian pada pendahuluan, dianalisa dan diinterpretasikan pada data penelitian. Analisa ini dimaksud untuk mengetahui distribusi frekuensi dan hubungan usia, paritas dan pendidikan ibu dengan pemeriksaan pap smear di Yayasan Kanker Indonesia Cabang Sumatera Selatan Tahun 2017.

Tabel 1 Distribusi Frekuensi Responden Berdasarkan Pemeriksaan Pap Smear di Yayasan Kanker Indonesia Cabang Sumatera Selatan Tahun 2017

\begin{tabular}{|c|c|c|c|}
\hline $\begin{array}{l}\mathbf{N} \\
\mathbf{0}\end{array}$ & $\begin{array}{c}\text { Pemeriksaan } \\
\text { Pap Smear }\end{array}$ & Frekuensi & Presentase \\
\hline 1 & $\mathrm{Ya}$ & 266 & 72,3 \\
\hline 2 & Tidak & 102 & 27,7 \\
\hline & Jumlah & 368 & 100,0 \\
\hline
\end{tabular}

Dari tabel 1 diatas menunjukkan ibu yang melakukan pemeriksaan pap smear lebih banyak berjumlah 266 orang (72,3\%) dibandingkan yang tidak melakukan pemeriksaan pap smear berjumlah 102 orang $(27,7 \%)$.

Tabel 2 Distribusi Frekuensi Responden Berdasarkan Usia Ibu di Yayasan Kanker Indonesia Cabang Sumatera SelatanTahun 2017 
Jurnal Kebidanan : Jurnal Medical Science Ilmu Kesehatan Akademi Kebidanan Budi Mulia Palembang Volume.8 No.2, Desember 2018

\begin{tabular}{|c|c|c|c|}
\hline No & Usia & Frekuensi & Presentase \\
\hline 1 & Resiko Tinggi & 259 & 70,4 \\
\hline 2 & Resiko Rendah & 109 & 29,6 \\
\hline & Jumlah & 368 & 100,0 \\
\hline
\end{tabular}

Berdasarkan tabel 2 menunjukkan ibu yang memiliki usia resiko tinggi lebih banyak berjumlah 259 responden $(70,4)$ dibandingkan ibu yang memiliki usia resiko rendah berjumlah 109 responden $(29,6)$.

Tabel 3 Distribusi Frekuensi Responden Berdasarkan Paritas Ibu di Yayasan Kanker Indonesia Cabang Sumatera SelatanTahun 2017

\begin{tabular}{cccc}
\hline No & Paritas & Frekuensi & Persentasi \\
\hline 1 & Resiko Tinggi & 68 & 18,5 \\
\hline 2 & Resiko Rendah & 300 & 81,5 \\
\hline & Jumlah & 368 & 100,0 \\
\hline
\end{tabular}

Sumber Data : Yayasan Kanker Indonesia Palembang

Dari tabel 3 di atas menunjukkan ibu yang memiliki paritas rendah lebih banyak berjumlah 300 responden (81\%) dibandingkan ibu yang memiliki paritas tinggi berjumlah 68 responden $(18,5)$.

Tabel 4 Distribusi Frekuensi Responden Berdasarkan Pendidikan Ibu di Yayasan Kanker Indonesia Cabang Sumatera SelatanTahun 2017

\begin{tabular}{cccc}
\hline No & Pendidikan & Frekuensi & Presentase \\
\hline 1 & Pendidikan Tinggi & 212 & 57,6 \\
\hline 2 & Pendidikan Rendah & 156 & 42,4 \\
\hline & Jumlah & 368 & 100 \\
\hline
\end{tabular}

Sumber Data : Yayasan Kanker Indonesia Palembang

Dari tabel 4 menunjukkan ibu yang berpendidikan tinggi lebih banyak berjumlah 212 responden $(57,6)$ dibandingkan ibu yang berpendidikan rendah berjumlah 156 responden $(42,4)$

\section{b. Analisa Bivariat}

Analisa ini dilakukan untuk mengetahui hubungan antara variabel dependen (pemeriksaan pap smear) dengan independen (usia, paritas dan pendidikan), dimana untuk melihat hubungan antara kedua variabel dengan menggunakan uji statistik Chi-square $\left(x^{2}\right)$ tingkat kemaknaan $\alpha$ $(0,05)$ dan kriteria pengujian hipotesis dengan membandingkan nilai probabilitas $(\rho)$ dengan nilai $\alpha(0,05)$.
1. Hubungan Antara Usia Ibu Dengan Pemeriksaan Pap Smear di Yayasan Kanker Indonesia Palembang Tahun 2017

Tabel 5 Hubungan Antara Usia Ibu Dengan Pemeriksaan Pap Smear di Yayasan Kanker Indonesia Cabang Sumatera Selatan Tahun 2017

\begin{tabular}{|c|c|c|c|c|c|c|c|c|}
\hline \multirow{3}{*}{$\begin{array}{l}\mathbf{N} \\
\mathbf{0}\end{array}$} & \multirow{3}{*}{$\begin{array}{l}\text { Usia } \\
\text { Ibu }\end{array}$} & \multicolumn{4}{|c|}{ Pemeriksaan Pap Smear } & \multirow{2}{*}{\multicolumn{2}{|c|}{ Jumlah }} & \multirow{3}{*}{$\rho$ Value } \\
\hline & & \multicolumn{2}{|c|}{ Ya } & \multicolumn{2}{|c|}{ Tidak } & & & \\
\hline & & $\mathbf{n}$ & $\%$ & n & $\%$ & \multicolumn{2}{|c|}{$\mathbf{N} \%$} & \\
\hline 1 & $\begin{array}{l}\text { Resiko } \\
\text { tinggi }\end{array}$ & 200 & 77,2 & 59 & 22,8 & 259 & 100 & $\begin{array}{c}0,001 \\
\text { (Bermakna) }\end{array}$ \\
\hline \multirow[t]{2}{*}{2} & $\begin{array}{l}\text { Resiko } \\
\text { Rendah }\end{array}$ & 66 & 60,6 & 43 & 39,4 & 109 & 100 & \\
\hline & & 266 & 72,3 & 102 & 27,7 & 368 & 100 & \\
\hline
\end{tabular}

Jumlah

Sumber Data : Yayasan Kanker Indonesia Palembang

Tabel 5 diatas menunjukkan dari 259 responden ibu yang memiliki usia resiko tinggi lebih banyak yang melakukan pemeriksaan pap smear berjumlah 200 responden $(77,2 \%)$ dibandingkan dengan yang tidak melakukan pemeriksaan pap smear berjumlah 59 responden $(22,8 \%)$. Dibandingkan ibu yang memiliki usia resiko rendah berjumlah 109 responden yang melakukan pemeriksaan pap smear berjumlah 66 responden $(60,6)$ dibandingkan dengan yang tidak melakukan pemeriksaan pap smear berjumlah 43 responden $(39,4)$.

Hasil uji chi-square diperoleh $\rho$ Value 0,001 $<\alpha 0,05$ yang berarti ada hubungan antara usia ibu dengan pemeriksaan pap smear. Sehingga hipotesis yang mengatakan ada hubungan antara usia ibu dengan pemeriksaan pap smear di Yayasan Kanker Indonesia Cabang Sumatera Selatan terbukti secara statistik.

\section{Hubungan Paritas Ibu Dengan Pemeriksaan} Pap Smear di Yayasan Kanker Indonesia Palembang Tahun 2017

Tabel 6 Hubungan Antara Paritas Ibu Dengan Pemeriksaan Pap Smear di Yayasan Kanker Indonesia Cabang Sumatera Selatan Tahun 2017

\begin{tabular}{|c|c|c|c|c|c|c|c|c|}
\hline \multirow{3}{*}{$\begin{array}{l}\mathbf{N} \\
\mathbf{0}\end{array}$} & \multirow{3}{*}{$\begin{array}{l}\text { Paritas } \\
\text { Ibu }\end{array}$} & \multicolumn{4}{|c|}{ Pemeriksaan Pap Smear } & & & \multirow{3}{*}{$\rho$ Volue } \\
\hline & & \multicolumn{2}{|c|}{ Ya } & \multicolumn{2}{|c|}{ Tidak } & \multicolumn{2}{|c|}{ Jumlah } & \\
\hline & & $\mathrm{n}$ & $\%$ & n & $\%$ & $\mathbf{N}$ & $\%$ & \\
\hline 1 & $\begin{array}{l}\text { Resiko } \\
\text { tinggi }\end{array}$ & 41 & 60,3 & 27 & 29,7 & 68 & 100 & $\begin{array}{l}0,022 \\
\text { (Bermakna) }\end{array}$ \\
\hline 2 & $\begin{array}{l}\text { Resiko } \\
\text { Rendah }\end{array}$ & 225 & 75,0 & 75 & 25,0 & 300 & 100 & \\
\hline & Jumlah & 266 & 72,3 & 102 & 27,7 & 368 & 100 & \\
\hline
\end{tabular}

Tabel 6 diatas menunjukkan dari 300 responden ibu yang memiliki paritas resiko rendah lebih banyak yang melakukan pemeriksaan pap smear berjumlah 255 responden $(75,0 \%)$ 
Jurnal Kebidanan : Jurnal Medical Science Ilmu Kesehatan Akademi Kebidanan Budi Mulia Palembang Volume.8 No.2, Desember 2018

dibandingkan dengan yang tidak melakukan pemeriksaan pap smear berjumlah 75 responden $(25,0 \%)$. Dibandingkan ibu yang memiliki paritas resiko tinggi berjumlah 68 responden yang melakukan pemeriksaan pap smear berjumlah 41 responden $(60,3)$ dibandingkan dengan yang tidak melakukan pemeriksaan pap smear berjumlah 27 responden $(29,7)$.

Hasil uji chi-square diperoleh $\rho$ Value 0,022 $<\alpha 0,05$ yang berarti ada hubungan antara paritas ibu dengan pemeriksaan pap smear. Sehingga hipotesis yang mengatakan ada hubungan antara paritas ibu dengan pemeriksaan pap smear di Yayasan Kanker Indonesia Cabang Sumatera Selatan terbukti secara statistik.

3. Hubungan Antara Pendidikan Ibu Dengan Pemeriksaan Pap Smear di Kanker Indonesia Palembang Tahun 2017

Tabel 7 Hubungan Antara Pendidikan Ibu Dengan Pemeriksaan Pap Smear di Yayasan Kanker Indonesia Cabang Sumatera Selatan Tahun 2017

\begin{tabular}{|c|c|c|c|c|c|c|c|c|}
\hline \multirow{3}{*}{$\begin{array}{l}\mathbf{N} \\
\mathbf{o}\end{array}$} & \multirow{3}{*}{$\begin{array}{l}\text { Pendidikan } \\
\text { Ibu }\end{array}$} & \multicolumn{4}{|c|}{ Pemeriksaan Pap Smear } & \multirow{2}{*}{\multicolumn{2}{|c|}{ Jumlah }} & \multirow{3}{*}{$\rho$ Volue } \\
\hline & & \multicolumn{2}{|l|}{ Ya } & \multicolumn{2}{|c|}{ Tidak } & & & \\
\hline & & $\mathrm{N}$ & $\%$ & $\mathrm{n}$ & $\%$ & $\mathrm{~N}$ & $\%$ & \\
\hline 1 & $\begin{array}{l}\text { Pendidikan } \\
\text { Tinggi }\end{array}$ & 194 & 91,5 & 18 & 8,5 & 212 & 100 & $\begin{array}{l}0,000 \\
\text { (Bermak- }\end{array}$ \\
\hline 2 & $\begin{array}{l}\text { Pendidikan } \\
\text { Rendah }\end{array}$ & 72 & 46,2 & 84 & 53,8 & 156 & 100 & \\
\hline & Jumlah & 266 & 72,3 & 102 & 27,7 & 368 & 100 & \\
\hline
\end{tabular}

Tabel 7 diatas menunjukkan dari 212 responden ibu yang berpendidikan resiko tinggi lebih banyak yang melakukan pemeriksaan pap smear berjumlah 194 responden $(91,5 \%)$ dibandingkan dengan yang tidak melakukan pemeriksaan pap smear berjumlah 18 responden $(8,5 \%)$. Dibandingkan ibu yang berpendidikan resiko rendah berjumlah 156 responden yang melakukan pemeriksaan pap smear berjumlah 72 responden $(46,2 \%)$ dibandingkan dengan yang tidak melakukan pemeriksaan pap smear berjumlah 84 responden $(53,8 \%)$.

Hasil uji chi-square diperoleh $\rho$ Value $0,000<\alpha 0,05$ yang berarti ada hubungan antara pendidikan ibu dengan pemeriksaan pap smear. Sehingga hipotesis yang mengatakan ada hubungan antara pendidikan ibu dengan pemeriksaan pap smear di Yayasan Kanker Indonesia Cabang Sumatera Selatan terbukti secara statistik.

\section{PEMBAHASAN \\ 1.Pemeriksaan Pap Smear}

Hasil penelitian yang dilakukan di Yayasan Kanker Indonesia Cabang Sumatera Selatan Tahun 2017 menunjukkan lebih banyak ibu yang melakukan pemeriksaan pap smear $(72,3 \%)$ dibandingkan ibu yang tidak melakukan pemeriksaan pap smear $(27,7 \%)$.Hasil univariat ini menunjukkan bahwa 368 reaponden, ibu yang melakukan pemeriksaan pap smear lebih banyak berjumlah 266 orang $(72,3 \%)$ dibandingkan yang tidak melakukan pemeriksaan pap smear berjumlah 102 orang $(27,7 \%)$.

\section{Usia}

Hasil penelitian yang dilakukan di Yayasan Kanker Indonesia Cabang Sumatera Selatan Tahun 2017 menunjukkan bahwa kelompok ibu yang berusia dan beresiko tinggi mengenai pemeriksaan pap smear lebih banyak $(70,4 \%)$ dinbandingkan dengan kelompok ibu yang berusia dan beresiko rendah $(29,6 \%)$.

Hasil analisis univariat ini menunjukkan bahwa ibu yang memiliki usia resiko tinggi lebih banyak berjumlah 259 responden $(70,4)$ dibandingkan ibu yang memiliki usia resiko rendah berjumlah 109 responden $(29,6)$.

\section{Paritas}

Hasil penelitian yang dilakukan di Yayasan Kanker Indonesia Cabang Sumatera Selatan Tahun 2017 menunjukkan bahwa kelompok ibu yang memiliki paritas dengan beresiko tinggi mengenai pemeriksaan pap smear lebih menurun $(18,5 \%)$ dibandingkan dengan kelompok yang memiliki paritas yang beresiko rendah $(81,5)$.

\section{Pendidikan}

Hasil penelitian yang dilakukan di Yayasan Kanker Indonesia Cabang Sumatera Selatan Tahun 2017 menunjukkan bahwa kelompok ibu yang berpendidikan tinggi mengenai pemeriksaan pap smear lebih banyak (212\%) dinbandingkan dengan kelompok ibu yang berpedidikan rendah $(156 \%)$.

\section{KESIMPULAN}

1. Distribusi frekuensi pemeriksaan pap smear sebanyak 266 orang (72,3\%) dibandingkan yang tidak melakukan pemeriksaan pap s mear berjumlah 102 orang $(27,7 \%)$.

2. Distribusi frekuensi ibu yang usia tinggi sebanyak 259 responden $(70,4)$ dibandingkan ibu yang memiliki usia resiko rendah berjumlah 109 responden $(29,6)$.

3. Distribusi frekuensi ibu yang paritas tinggi lebih sedikit 68 responden $(18,5 \%)$ dibandingkan ibu 
yang memiliki paritas rendah berjumlah 300 responden $(81,5)$.

4. Distribusi frekuensi ibu yang pendidikan tinggi lebih banyak 212 responden $(57,6)$ dibandingkan ibu yang pendidikan rendah berjumlah 156 responden $(42,4)$.

5. Diketahui ada hubungan antara usia dengan pemeriksaan pap smear di yayasan kanker indonesia palembang 2017 dengan pvalue = $0,001(\alpha<0,005)$

6. Diketahui ada hubungan antara paritas dengan pemeriksaan pap smear di yayasan kanker indonesia palembang 2017 dengan $\rho$ value = $0,022(\alpha<0,005)$

7. Diketahui ada hubungan antara pendidikan dengan pemeriksaan pap smear di yayasan kanker indonesia palembang 2017 dengan pvalue $=0,012(\alpha<0,005)$.

\section{SARAN}

\section{Bagi Tempat dan Penelitian}

Dengan adanya hubungan usia, paritas dan pendidikan dengan pemeriksaan pap smear di Yayasan Kanker Indonesia Palembang agar lebih banyak memberikan informasi penyuluhan tentang pemeriksaan pap smear supaya dapat mencegah terjadinya kanker serviks.

\section{Bagi Institusi}

Diharapkan pada tahun yang akan datang institusi pendidikan dapat memberikan waktu lebih lama untuk melakukan penelitian agar dapat lebih akurat.

\section{Bagi Penulis}

Perlu dilakukan penelitian lanjut mengenai hubungan antara usia, paritas, pendidikan dengan pemeriksaan pap smear. Untuk menyempurnakan pancangan penelitian dengan disarankan mengkombinasi metode kuantitatif dengan metode kuakitatif, sehingga dapat memperoleh pemahaman yang lebih mendalam mengenai hubungan antara usia, paritas, pendidikan dengan pemeriksaan pap smear.

\section{DAFTAR PUSTAKA}

A.Aziz Alimul Hidayat. 2014. Metode penelitian kebidanan dan teknik analisa data. Jakarta: Salemba Medika

Astrid Savitri, dkk. 2015. Kupas Tuntas Kanker Payudara, Leher Rahim, dan Rahim. Yogyakarta: Pustaka Baru Press.

Depkes RI. 2014. Profil kesehatan Indonesia. Jakarta : Depkes RI.
Dinas Kesehatan Prov. Sumatera Selatan. 2014. Profil Kesehatan Provinsi Sumatera Selatan 2014. Palembang.

Kementerian Kesehatan RI. 2015. Situasi Penyakit Kanker. Pusat Data dan Informasi, Jakarta.

Koes Irianto. 2015. Epidemologi Penyakit Tidak Menular. Penerbit Alfabeta, Bandung.

Perkumpulan Keluarga Berencana, 2014. Sumatera Selatan

Yayasan Kanker Indonesia Palembang, 2017

World Health Organation (WHO). 2014 Kanker Payudara, Leher Rahim, dan Rahim. Indonesia. 
Jurnal Kebidanan : Jurnal Medical Science Ilmu Kesehatan Akademi Kebidanan Budi Mulia Palembang Volume.8 No.2, Desember 2018 
